\title{
Polysèmes
}

Revue d'études intertextuelles et intermédiales

\section{In the Name of Blue: Blue Joyce, Blue Gass, Blue Klein}

\section{Marie-Dominique Garnier}

\section{Q OpenEdition \\ 1 Journals}

\section{Electronic version}

URL: http://journals.openedition.org/polysemes/576

DOI: 10.4000/polysemes.576

ISSN: 2496-4212

Publisher

SAIT

\section{Electronic reference}

Marie-Dominique Garnier, «In the Name of Blue: Blue Joyce, Blue Gass, Blue Klein », Polysèmes [Online], 14 | 2015, Online since 18 November 2015, connection on 10 October 2020. URL : http:// journals.openedition.org/polysemes/576; DOI : https://doi.org/10.4000/polysemes.576

This text was automatically generated on 10 October 2020

Polysèmes 


\title{
In the Name of Blue: Blue Joyce, Blue Gass, Blue Klein
}

\author{
Marie-Dominique Garnier
}

Blue as you enter it disappears.

William Gass, On Being Blue, 1976

What follows runs in the small paronomastic interval between (in French) "couleur" and "couler"-an interval which cleaves color to what flows, comes off, seeps and follows suit: in other words to fluctile patterns, queer modalities running across boundaries, leaving grammatical categories ajar. The thin interval between "couleur" and "couler" emits no signs of being destined to evolve beyond the level of sheer surface resemblance or chance aural connections between two unrelated words spawned by two distinct Latin roots: colorem (color); colare: (to flow). Although in English no similar conflation seems possible, a number of comparably unstable patterns in the way the word "color" behaves can be traced. "Color" rubs elbows with a number of restless neighbours, such as a "colander", for example, an object which reveals a possible overlap between color and what seeps through, filters or leaks; or the verb "to color" used colloquially, with an adjective in tow (as in "color me beautiful" or "color me curious"), in which "coloring" equals calling, thus turning "color" into a pliant, stretchable term. Or again in Shakespeare's English, the term "hue" is repeatedly invited to follow unstable semantic lines, running as it often does in many sonnets from "hew" to "Hugh" to "you" and back. "Color" itself liberates a chain reaction of puns in the opening scene of Romeo and Juliet (where "collar" brings up "choler").

Blue (but what is blue?) offers a particularly promising case in the study of a "running" or runaway transitivity in the domain of semantic and linguistic categorization. Its actual physical as well as verbal specter is as wide as its referential metamorphoses. Its "eloquence", to borrow Jacqueline Lichtenstein's engaging term, may seem endless and endlessly chatty, although on second thoughts "eloquence" may not be the aptest way of describing the critical force which writers such as Joyce or Gass have released "out of" the blue, on blueness or "being" blue. Eloquence implies a linguistic substratum or " logos": a tongue. Blue, as this essay attempts to show, explores along with other 
"colors" the porosity of boundaries and the mobility of limitrophic zones. It is not easily amenable to "logos" and language-as the line quoted from Gass in the above epigraph makes clear or rather unclear: how eloquent is "blue" in Gass's sentence? What position does it occupy? From a position of "being entered", it shifts to the opposite end, to regain its force as the grammatical subject of "disappears"-with a moment of uncertainty in the reading process around the status of "it". Both Joyce and Gass's writings have captured less than verbal, marginally eloquent critical moments out of the blue-de but en blanc. Blue/blau/blank stem from the same mobile, transplantable root, thus forming a mobile rhizome rather than a single root. Bla (old norse) covers the semantic space taken up by the Latin lividus, while blavu (blue) is akin to flavo, flavus, yellowish grey. The labile "substance" of William Gass's 1976 philosophical inquiry On Being Blue operates a further displacement by linking "being" and "blueness", contaminating ontology with color to the effect that "being" in the title loses ground and behaves as a mere rhythmic stand, a background against which blue is fully displayed, deployed as a "country"-poetically placed, on Gass's map, in the uncertain contact zone between real territories and female bodies (countries and "cunt"/tries).

What follows attempts, in other words, to measure the amount of resistance encountered in the vicinity of color, which as Jacques Derrida argued in Dissemination operates along the same unstable lines as every linguistic and cultural "pharmakos". Like writing, color operates as a "substance" (a "pharmakos") which resists the format of the "substantive", of substance-oriented language categories. Derrida quotes a previous study of Plato before commenting:

This has not gone unnoticed: '[...] isn't the word pharmakon, which means color, the very same word that applies to the drugs of sorcerers and doctors?' [...] The word pharmakon, then, also designates pictorial color [...] The Republic also calls the painters'colors pharmaka (420c) [...] Pharmakon is also a word for perfume. A perfume without essence, as we earlier called it a drug without substance. It transforms order into ornament, the cosmos into a cosmetic. (Derrida 140-142)

Color (as pharmakon) runs, at a (safe) distance from essence and from ontology. The line to be followed here inhabits the thin space that separates "being" from "blue". Blue runs, and as William Gass's text makes clear it runs into being (both in the sense of an encounter and of a metamorphosis, or of a becoming). Blue runs across literature, constituting a literal as well as literary case of what Deleuze and Guattari have termed a "ligne de fuite" or "line of flight", to be more aptly retranslated here perhaps as a "line of seepage", a runaway line, to follow Deleuze and Guattari's fluid metaphor. A line of blue runs from Joyce and Gass to Klein, not only out of the color blue but also in the "name" of blue, which as we have seen belong to a vast, labile color spectrum (involving white, grey, blue and yellow). Blue initiates a form of stuttering, perceptible as much in Gass's "being blue" as in Joyce's "blue Bloom", a line which also crosses over into the forbidden territory of the proper name: how blue is Gass's own name? What color is "Gass"?

\section{Reading the adiaphane}

Blue enters modernity through many doors, most perceptibly in James Joyce's Ulyssesa very "blue book", which Joyce had bound between Mediterranean-blue covers. A "purple" patch in Joyce criticism, the opening paragraph of episode 3 of Ulysses known 
as "Proteus" has yielded numerous critical readings, none of which rids it completely of its opacity. Strolling on Sandymount beach, Stephen meditates on the "ineluctable modalities of the visible", a phrase borrowed from Aristotle's theory of vision in The Treatise of the Soul. A figure of the artist as a young Aristotelian, Stephen also embodies a proto-reader, the ideal figure of a gatherer of traces on the "beach" of knowledge. "Coloured signs" abound, including in the use of the foreign, Italian word " color" in a quotation from Dante (a term which again makes color "run"):

Ineluctable modality of the visible: at least that if no more, thought through my eyes. Signatures of all things I am here to read, seaspawn and seawrack, the nearing tide, that rusty boot. Snotgreen, bluesilver, rust: coloured signs. Limits of the diaphane. But he adds: in bodies. Then he was aware of them bodies before of them coloured. How? By knocking his sconce against them, sure. Go easy. Bald he was and a millionaire, maestro di color che sanno. Limit of the diaphane in. Why in? Diaphane, adiaphane. If you can put your five fingers through it, it is a gate, if not a door. Shut your eyes and see.

Stephen closed his eyes to hear his boots crush crackling wrack and shells. You are walking through it howsomever. I am, a stride at a time. A very short space of time through very short times of space. Five, six: the Nacheinander. Exactly: and that is the ineluctable modality of the audible. Open your eyes. No. Jesus! If I fell over a cliff that beetles o'er his base, fell through the Nebeneinander ineluctably. I am getting on nicely in the dark. My ash sword hangs at my side. Tap with it: they do. My two feet in his boots are at the end of his legs, nebeneinander. Sounds solid: made by the mallet of Los demiurgos. Am I walking into eternity along Sandymount strand? Crush, crack, crick, crick. Wild sea money. Dominie Deasy kens them a'.

Won't you come to Sandymount,

Madeline the mare?

Rhythm begins, you see. I hear. Acatalectic tetrameter of iambs marching. No, agallop: deline the mare. Open your eyes now. I will. One moment. Has all vanished since? If I open and am for ever in the black adiaphane. Basta! I will see if I can see. See now. There all the time without you: and ever shall be, world without end. (Joyce 31 [U: 3, 1-28]) ${ }^{1}$

The chapter's opening meditation-in-(physical)-progress reads as a moment of applied philosophy in which Aristotle's text on perception is submitted to a blind test, as Stephen walks with his eyes shut in the entire passage until the last paragraph, until the final, ambivalent affirmation "I will see if I can see"-a sentence which branches off into two opposite directions, depending on whether "see" is used in the weak, phatic sense of "to find out" or in the strong, epistemic sense of "to perceive". Stephen's opaque meditation on a beach or "strand", rather, moves away from Aristotle's invention of the diaphanous towards a word he himself has coined-the "adiaphane"by which brute materiality is implied, in other words the resistance of solid objects. The course of Stephen's aesthetic and peripatetic philosophizing is complicated by a parallel meditation on the audible, imported from Lessing, as a pair of German terms designating two regimes (spatial juxtaposition versus temporal succession) are incorporated into Stephen's disquisition. The texture of Joyce's poetic prose, however, goes against the grain of Aristotelian and post-Aristotelian distinctions. The force of this passage rests on its capacity to deconstruct Lessing's oppositions between spatial juxtapositions and narrative succession. Stephen's fabrication of the "adiaphane" and the resulting polarity diaphane/adiaphane is thrown off balance, deconstructed as it is caught in a non-visual semantic network, in which "adiaphane" ceases to operate as a visual term to become part of a rhythmic sequence (a door/a stride/acatalectic/ agallop/adiaphane). 

between diaphane/adiaphane, Nacheinander/Nebeneinander. The two paragraphs forming Stephen's portable aesthetic manifesto pertain to the visible as much as to the audible, thus blurring Lessing's distinction and questioning the text's fragmented layout, its divided arrangement on either side of a central pause or blank. They pertain to the visual mode, forming two quasi-identical strips of uninterrupted text articulated on either side of the blank space initiated by the invitation to "shut your eyes and see". They form, not one, but two "strands" - two interchangeable threads or yarns in the texture of Joyce's blocks of "lines" or "out-lines" or "de-lines"-a term here given specific prominence as Stephen isolates it for rhythmic purposes.

The many colors strewn in the first paragraph seem to meet the agenda of a realistically coded seascape, in other words the depiction of a tainted shore bearing a number of disheartening, diseased "coloured signs" reflecting a perverted Irish color scheme: "snotgreen, bluesilver, rust". But what exactly is a "coloured sign"? Beyond the obvious answer, the claim that Joyce resorts to a realistic, near-mimetic prose is challenged by the fact that Stephen's "coloured signs" defy substance and referential stability. None of them belongs to a colourfast category. Joyce's body-dependent color scheme is less than stable: bluesilver, contrary to silverblue, has not been promoted to lexicographic status and is not featured in any dictionary.

7 A strangely color-bound word affects Stephen's description of the Irish strand, imported in a quotation from Dante's Divine Comedy. There, Aristotle is described as the "maestro di color qui sanno", which reads either one of Dante's deliberate puns or as an invitation to misread the Italian plural pronoun "color" which has nothing to do with color, but which this particularly prominent passage invites to "run" or to come off differently. "Color" in other words is not colorfast: it is made to "run" (as fast as possible), to drift and capsize along, one might add, with the rest of the referential palette-or, to quote Stephen's Hamlet-inspired remark, it is made to "beetle over" its substantial "base".

8 Jean-Michel Rabaté has written extensively on this particular passage and on what he describes as a reader's mistake-as his own misreading of an Italian plural pronoun, in a context otherwise studded with colored signs: “j'y ai toujours lu par un contresens que je ne me hâterai pas de corriger, qu'il y était question du rapport entre les couleurs et le savoir". He concludes, arguing against the "eloquence" of color, and in favor of the stubborn silence of its foreign look-alike: "il faut laisser à ce texte son opacité" (Rabaté 24). Color, confined to subservience in Aristotle's aesthetics, is here given a chance to affect textuality, to haunt langage like an unwanted "pharmakos". A similar grammatical twist affects Stephen's off-hinge statement in the second paragraph of the same passage that "My two feet in his boots are at the ends of his legs, nebeneinander". Stephen is wearing a pair of second-hand or second-"foot" boots handed down to him by Malachi Mulligan, which accounts for the phrase "his boots". "His legs" however, undermines the "stance" of the subject, turning Stephen either into an extension of Mulligan whose hand-me-down shoes and trousers he's wearing, or metamorphosing himself into a schizoid type, an anacoluthic subject with outsourced "legs"-a subject who beetles over his literal as well as grammatical base.

One of the statements made in this colorful, concrete and yet abstract text is to link color, conceived as a subservient aesthetic quality, to questions of ontology or "being". The question of being surfaces in Stephen's meditation, which links essence twice to a 
matter of perceptual existence: "Signatures of all things I am here to read [...] I am, a stride at a time". Despite the apparently minor, easily historicized detail of the colors "bluesilver" or "snotgreen" brought up in Stephen's painterly description of the Dublin strand (an example of Irish "greenness" now brought low, rendered subaltern, one might argue), both colors "run" or flow into the color chosen for the cover of Ulysses, emblematically draped in a shade of blue Joyce wanted as close as possible to the color of the Greek flag. One shade of "bluesilver" runs into another, to the effect that the book's blueness belongs to the same specter as the "snotgreen" of Stephen's flânerie by the "nearing tide". In Joyce's "blue" book, the color "blue" belongs to a spectrum no dictionary will contain, as it is an extremely "fast" color, a color fast enough to run from one end to the other, from more or less stabilized national allegories (Irish green, Greek blue) to propagational principles-such as the trans-nominal force that opens up the territory of the proper name to color, as in Bloom's resonant name.

\section{On Being Blue, on Being Bloom: Noms de bleu} quality back into the field of writing-as-thinking, collapsing being and blueness into one. It experiences color as sound, much against the grain of spatial/temporal binaries -to the effect that, yet once more, eloquence may not be the notion or concept required here. One of Gass's definitions of blue is penned in a language which has literally nothing to say, but everything to perform: "blue is the color of the mind in borrow of body; it is the color consciousness becomes when caressed; it is the dark inside of sentences, sentences which follow their own turnings inward out of sight like the whorls of a shell [...]" (Gass 57).

11 On Being Blue begins with a rhizoming list of things blue, objects of all descriptions: "blue pencils, blue noses, blue movies, laws, blue legs and stockings, [...] hair rinse, blueing, bleach, Blue Peter, the constantly increasing absentness of Heaven (ins Blaue hinein, the Germans say), [...] the color of everything that's empty" (Gass 7). Gass then probes the etymology of blue, only to reach the following, apparent aporia: "Blue: bright, with certain affinities for bael (fire, pyre), with certain affinities for bald (ballede), with certain affinities for bold. Odd" (Gass 7).

ess too surfaced in Stephen's Protean meditation, in his reminiscence of the common medieval belief that Aristotle was a bald-pated millionaire. Agreeing to walk in the footsteps of Gass, however, one could locate, beneath the "baldness" of Aristotle, one of the buried etymologies of "blue", an adjective suggesting the degree of phenomenal existence of any shiny surface which light happens to glance on. The blue/ bleu/blau series is no different, etymologically, from the lustrous effects of the French blanc, white, akin to blank at the paronymic level at least. Gass's book is dedicated, beautifully, "to those who live in the country of the blue", a country which can only be entered with an ear for foreign languages, for strange encounters in the open territory of self-deconstructing associations: between "contrée" and "contre", "Gegend" and "gegen ", "country" and the "contrary": a locus whose name opens door-wise (or is it gatewise) onto unstable zones of exchange, onto foreign and fluctile identities.

William Gass quotes, among other sources of fascination, Wilhelm Reich, the believer in orgone energy and the inventor of the orgone accumulator, for whom "blue is the specific color of orgone energy within and without the organism" (Gass 34). The salient 
terms in such a quotation are neither orgone nor energy, but "within and without", a porous adverbial juxtaposition opening up the sense of a generalized tactile connectivity, regardless of the limits of seeing. Reich adds: "a completely darkened room, if lined with iron sheet metal, (the orgone room) is not black, i.e. free of light, but bluish or bluish gray" (Gass 34).

Gass's philosophic enquiry leads him to bring up Joyce's Leopold Bloom or "Bloowho" (Joyce, U: 11, 86), one of the haunting blue notes of Ulysses, a character whom Joyce links to bluishness in writing, as in the following sentence: "Light sob of breath Bloom sighed on the silent bluehued flowers" (Joyce, U: 11, 457). In such an example the subject has become what could be called a blue subject, the non-subject of multiple transitive connections. It has become, in one single breathless breath, "light sob of breath Bloom", a rhythmic subject of syncopation born from a complex arrangement of liquids and sibilants, of l's and s's. Joycean blue sits restlessly between shade and tone, demanding constant beat, and, preferably, tactile reading-a ceaseless tapping, a blind tapping or tapping into, rather than the gift of a pair of eyes, or ears. Gass goes as far as to deconstruct his "own" subject, to liquidate blue and question its steadfastness or colorfastness-"blue as you enter it disappears" (Gass 86).

One of the ways in which it disappears is by becoming strangely involved in the roots, in the etymology of the verb to "be": the title of Gass's book, On Being Blue, operates less as a title to be read as a piece to be heard, a rhythmic performance balanced on the cusp of a repeated sequence, a line of b's, a b-line, to the effect that "on" reads both ways: as subject-matter and as cause for addiction.

In the space of a title, Gass's writing shifts from referentiality or representation to production: the twofold, minimal, reversible beat of Gass's writing beats blue into rhythmic shape. Within the lulling beat of $a$ double $b$ emerges the mobile gerund "being", here devoid of the substantive force of ontology, displaced towards repetition and transitoriness. "Being" in other words is made to operate as a twin or body-double of blue. "Being blue" may be, precisely, the "color" of knowledge, the unheard-of color que sanno, the transitive "color" swift enough to cross langages (English/Italian) and to operate with the wildness of a rhizome (as in French: couloirs/couler). This form of transitive "knowledge" operates in and out of the proper name of Bloom, which Joyce manipulates as a flowing, rhizoming principle, for example in the phrase "Bloom's blue-hued flower" found on the surface of one of Ulysses' most musical, syncopated lines: "Light sob of breath Bloom sighed on the silent bluehued flowers" (Joyce, 1922, U. 11: 457). Aesthetically, the shape of all shapes, the flower, is reconnected to the shapelessness of what flows, in the fluctile sense. Blue is a "flow-er" as much as a flower.

The oddness or aporia which Gass stumbled upon when reflecting on the etymology of "blue" is echoed in another philosophical enquiry, in the recent French retranslation of Heidegger's Grammaire et étymologie du mot être, originally published in Einführung in die Metaphysik (1953). There are two main roots, Heidegger explains, for "being" in IndoEuropean: *es, esse, and the German sein, understood as "ce qui se tient en soi-même", (what stands as itself), and *blû/*bheu, linked to what spreads ("s'épanouir, étendre son règne", to quote Pascal David's fertile, blooming translation) (Heidegger 61), what grows or literally, what blooms. Strangely, uncouthly, the two roots Heidegger exploits grow and proliferate in the very names Joyce gave to his two post-Odyssean travelers, in the names of Stephen and Bloom, each of them acting as a version of being, a standing and 
a growing, a "stephening and a "blooming". At the end of the Portrait of the Artist as a Young Man Stephen the stander gives such a root particular prominence in the book's final lines: "Old Father, old Artificer, stand me now and forever in good stead" (Joyce 1916, 253). Bloom, on the other hand, harbors growth, blooming, as its very life principle. The rhizoming pattern such a name seems to encourage rhizomes on, one might add, from William Gass's treatment of blue to Yves Klein's material negotiations with gas-gun, fire, and blueness.

\section{More Gas}

Yves Klein is known, essentially, as the inventor and promoter of I.K.B. monochrome blue. Less known is his fascination for the blueness of gas, a shade of blue no acronym can ever fix in place. Klein's research led him to collaborate with engineers working with the French company Gaz de France in order to have access to the large quantities of gas his heavy-duty gas gun required. Beyond Klein's declarations of interest in the element of fire, and his theorizing on three main monochromes (blue, gold, and pink, allegedly three colors found in fire), what Klein was deeply interested in was neither blue per se, nor fire. His constant involvement was with... gas, ${ }^{2}$ with the brightness of gas, which depending on the temperature at which it consumes itself varies from one end of the spectrum to the other. Gas, at this stage, can be spelt whichever way one likes-with one or two s's, if one agrees to move supply from one end of the name (the common) to the other (the proper). Blueness, one might argue, is one of the names of transitivity or limitrophy: rather than a case of eloquence, it runs between. In between William Gass and Yves Klein grows or flows the material immateriality of gas-to be found, too, as a constant leitmotiv in Joyce (for example in his frequent inclusion in various narratives of the gasworks near Dublin, or to quote one of his youthful poems, in Gas from a Burner).

At the end of Jean-Michel Rabaté's book-length study of the color of modernity, in the chapter titled "La couleur fantôme"-the phantom color of modernity-the critic quotes a French poet whose poem walks the thin line, Rabaté explains, between "couleur" and " douleur" (Rabaté 47-49). But the poem, quite fittingly, is not only about color-but about the "coloured sign", to borrow Stephen Dedalus' Aristotelian phrase. Or more exactly about what signs, what leaves a name on paper. It bears, of all names, the "coloured sign" of a flowing signature: Alain Coulange.

\section{BIBLIOGRAPHY}

Derrida, Jacques. Dissemination. Trans. Alan Bass. Chicago: U of Chicago P, 1982.

Gass, William. On Being Blue, a Philosophical Inquiry. Boston: Godine, 1976.

Joyce, James. Portrait of the Artist as a Young Man (1916). Harmondsworth: Penguin Books, 1976.

Joyce, James. Ulysses (1922). Harmondsworth: Penguin Books, 1984. 
Jouffroy, Alain. Manifeste pour Yves Klein. Besançon : Virgile, 2006.

Lichtenstein, Jacqueline. La Couleur éloquente. Paris : Flammarion, 2003.

Rabaté, Jean-Michel. La Pénultième est morte. Seyssel : Champ Vallon, 1993.

\section{NOTES}

1. References to Joyce's Ulysses cite the book as follows: U : chapter and line number.

2. To the point that he would order sparkling water "de l'eau minérale gazeuse", at restaurants, to accompany, for example, a dish of oysters (62).

\section{ABSTRACTS}

This essay attempts to make color "run" in various ways, to make it run fast (color-fast) between ontological and logical categories. Three ways of becoming-blue, three steps into writing/ painting via the color blue are traced: blue Joyce, blue Gass, blue Klein. Three "countries" of the blue, opening onto labile regimes of in-betweenness: between two roots of the verb "to be" (esse) *blû, both active in Joyce's Ulysses), or between proper and common nouns (from William Gass to Klein's gas or Joyce's Gas from a Burner).

Cet essai fait "couler" la couleur à partir de trois textes mettant variablement en défaut les catégories ontologiques et logiques. Trois devenirs-bleus, trois entrées en écriture/peinture via le "bleu" sont ici pris en filature : bleu Joyce ; bleu Gass ; bleu Klein. Trois "pays" du bleu où il s'agit de laisser entrer trois logiques labiles ou entre-deux: entre deux racines du verbe être (esse/*blû, à partir d'Ulysses de James Joyce), ou entre noms propres et noms de "choses" (de William Gass au gaz d'Yves Klein, ou au "gaz" de Gas from a Burner de James Joyce).

\section{INDEX}

Mots-clés: couleur, ligne de fuite

Keywords: colour, line of flight

oeuvrecitee On Being Blue, Ulysses

\section{AUTHORS}

\section{MARIE-DOMINIQUE GARNIER}

Marie-Dominique Garnier est Professeur de Littérature de langue anglaise et d'Études de genre à l'Université Paris 8. Elle a récemment co-dirigé deux volumes sur l'écriture d'Hélène Cixous (Cixous sous X, PUV 2010, et Cixous Party/Partie de Cixous, Peter Lang 2014), et publié des articles à l'intersection de la littérature et de la philosophie. Elle a traduit le texte expérimental consacré à 
la philosophie, l'architecture et l'œuvre plastique d'Arakawa, Helen Keller or Arakawa, publié aux États-Unis en 1994, par Madeline Gins, à paraître. 